\title{
PENERAPAN DAN PENILAIAN SISTEM INFORMASI MANAJEMEN \\ DAERAH (SIMDA) DI KABUPATEN PURWOREJO DALAM MEMBANTU PENGELOLAAN AKUNTANSI PEMERINTAHAN
}

\author{
Eko Darmawan Suwandi \\ Sekolah Tinggi Ilmu Ekonomi Putra Bangsa
}

\begin{abstract}
The purpose of this study was to determine the application and assessment of regional management information systems in Purworejo help the management of government accounting.

This study is a qualitative research with this type of case study approach (case study). Case study aims to explore a particular case in more depth by involving the collection of various resources.

The results of the research study showed SIMDA application in Purworejo with the accrual system capable manghasilkan information with accuracy or degree of truth better when compared to manual data processing. Assist Leader (Head of Region, the Regional Secretary, as the Budget User Head SKPD) in making decisions appropriate data and information. Internal Control System runs well starting from budgeting, administration until the reporting.
\end{abstract}

Keywords: SIMDA, SKPD, management accounting

\section{PENDAHULUAN}

\subsection{Latar Belakang Peneltian}

UU No. 32 Tahun 2004 tentang pemerintah daerah dan UU No. 33 Tahun 2004 tentang perimbangan keuangan atas pemerintah pusat dan pemerintah daerah merupakan langkah awal yang dilakukan pemerintah untuk merespon adanya tuntutan reformasi sektor publik di indonesia. Salah satu upaya kongkrit dalam mewujudkan transparansi dan akuntabilitas adalah dalam hal penyususnan, penyajian laporan pertanggungjawaban, transparansi yang tumbuh adalah keterbukaan pemerintah dalam memberikan informasi yang terkait dengan aktifitas pengelolaan sumber daya publik kepada pihak-pihak yang memerlukan informasi. Pemerintah daerah selaku pengelola dana publik harus mampu menyediakan informasi keuangan yang diperlukan secara akurat, relevan, tepat waktu dan dapat dipercaya (akuntabel).

Laporan keuangan yang baik harus akurat, relevan, tepat waktu dan dapat dipercaya, sehingga pemerintah perlu mengubah sistem pengelolaan keuanganya pada saat laporan keuangan yang dihasilkan dirasakan masih kurang transparan dan akuntabel, 
karena belum menggunakan sistem akuntansi yang sesuai dengan Standar Akuntansi Pemerintah (SAP), hal tersebut menentukan dilaksanakannya akuntansi dalam pengelolaan keuangan daerah, bukan lagi pembukuan seperti yang dilaksanakan selama ini.

Sistem akuntansi memungkinkan tidak hanya menghasilkan laporan realisasi anggaran, tetapi dapat dihasilkan laporan yang lain seperti neraca dan laporan arus kas, disamping itu dengan penerapan sistem akuntansi keuangan daerah diharapkan mengcegah terjadinya penyimpangan dalam pengelolaan keuangan, sehingga tuntutan akan trasparansi efektivitas, efisiensi dan akuntabel pengelolaan keuangan akan terwujud. UU No. 17 Tahun 2003 pasal 31 menyebutkan bahwa Gubernur, Bupati dan Wali Kota menyampaikan rancangan peraturan daerah tentang pertanggungjawaban pelaksanaan APBD kepada DPRD berupa laporan keuangan yang setidaktidaknya terdiri dari: Laporan Realisai anggaran, Neraca, Laporan Arus Kas dan Catatan atas Laporan Keuangan. PP No 71 tahun 2010 menyebutkan APBN/APBD bahwa sistem akuntansi pemerintahan (SAP) berbasiskan akrual yaitu mengakui pendapatan, beban, aset, utang, dan ekuitas dalam pelaporan finansial.

Penerapan akuntansi merupakan salah satu upaya untuk memperbaiki pelaporan dan tanggungjawab sehingga dapat memenuhi karakteristik trasparan dan akuntabel. penerapan akuntansi sebagai salah satu wujud pelaksanaan reformasi pengelolaan keuangan daerah dalam rangka mewujudkan good governance dalam praktiknya mengalami beberapa permasalahaan teknis operasional ditingkatkan pelaksanaan pemerintah daerah harus mempunyai srategi-strategi untuk menghadapi permasalahanpermasalahan meminimalkan keterbatasan-keterbatasan yang mewujudkan pengelolaan keuangan yang semakin trasparan dan akuntanbel dengan menerapkan Sistem Akuntansi Keuangan Daerah (SAKD).

Pengelolaan keuangan harus mengacu kepada Peraturan Pemerintah No. 58 tahun 2005 tentang Pengelolaan Keuagan Daerah dan Permendagri No.13 tahun 2006 yang telah diperbaharui dengan Permendagri No. 59 Tahun 2007 tentang pedoman pengelolaan keuangan daerah, mulai dari penyusunan anggaran, pelaksanaan anggaran sampai pertanggungjawaban penggunaan anggaran daerah. Sedangkan penyajian laporan keuangan pemerintah daerah harus mengacu kepada Peraturan Pemerintah No.24 tahun 2005 tentang Standar Akuntansi Pemerintah. Pengelolaan keuangan daerah mencakup aktivitas; perencanaan, pelaksanaan, pengawasan, pengendalian, pelaporan dan evaluasi (PP. No. 58 tahun 2005). Pengawasan dan pengendalian dalam pengelolaan keuangan daerah dimaksudkan agar setiap rupiah yang dibelanjakan pemerintah berdampak terhadap kepentingan dan kebutuhan publik dan dapat 
dipertanggungjawabkan kepada publik. Pengelolaan keuangan daerah yang dapat dipertanggungjawabkan ditandai dengan hasil laporan keuangan yang transparan dan akuntabel.

Pemerintah daerah Kabupaten Purworejo harus melakukan akuntansi dalam menyusung laporan keuangan daerah hal ini agar keuangan yang dihasilkan berguna dan dapat menjadi bahan pertimbangan dalam mengambil keputusan ekonomi, sosial dan politik dalam rangka penerapan akuntansi keuangan daerah. Berdasarkan uraian diatas maka peneliti tertarik untuk melakukan penelitian tentang penerapan dan penilaian sistem akuntansi keuangan daerah sebagai evaluasi pengelolaan keuangan daerah Kabupaten Purworejo.

\subsection{Rumusan Masalah}

Berdasarkan pada uraian tersebut diatas yang menjadi permasalahan dalam kegiatan penelitian ini adalah "Bagaimana penerapan dan penilaian sistem informasi manajemen daerah di Kabupaten Purworejo dalam membantu pengelolaan akuntansi pemerintahan?’.

\subsection{Tujuan Penelitian}

Berdasarkan permasalahan yang telah dirumuskan diatas, maka tujuan yang hendak dicapai dalam penelitian ini adalah untuk mengetahui penerapan dan penilaian sistem informasi manajemen daerah di Kabupaten Purworejo dalam membantu pengelolaan akuntansi pemerintahan.

\section{KAJIAN TEORI}

\subsection{Akuntansi}

Menurut Suwardjono (2006: 6) akuntansi adalah kegiatan atau fungsi penyedian jasa. Fungsinya adalah menyediakan informasi kualitatif tentang unuit-unit usaha ekonomik, terutama yang bersifat keuangan yang diperkirakan manfaat dalam pengambilan keputusan ekonomik. Akuntansi menghasilkan informasi tidak hanya untuk kepengtingan pengendalian dan pertanggungjawaban tetapi lebih luas lagi yaitu menghasilkan informasi untuk mempengaruhi para pelaku ekonomi dalam perekonomian.

\section{Accounting Principles Board} (1970): "akuntasi adalah suatu kegiatan jasa, yang fungsinya menyediakan informasi kuantitatif, terutama yang bersifat keuangan tentang entitas ekonomi yang dimaksud berguna dalam pengambilan keputusan ekonomi dan pilihan- pilihan nalar berbagai alternatif arah tindakan" (Halim 2007: 32). Selanjutnya Menurut American Accounting Associatian (1966): "Akuntansi adalah suatu proses pengindentifikasian, pengukuran, pencatatan dan pelaporan transaksi ekonomi (keuangan) dari suatu organisasi/entitas yang dijadikan sebagai informasi dalam rangka pengambilan keputusan ekonomi oleh pihak-pihak yang memerlukan" (Halim, 2007: 32).

Berdasarkan kedua definisi diatas dapat di ketahui bahwa fungsi 
akuntansi adalah penyedian informasi kuantitatif, terutama yang bersifat keuangan tentang entitas ekonomi. Informasi yang di hasilkan oleh akuntansi dimaksudkan agar berguna sebagai input yang di pertimbangkan dalam pengambilan keputusan ekonomi yang rasional. keputusan ekonomi adalah keputusan yang menyangkut ilmu ekonomi, tidak terbatas pada keputasan yang berkaitan dengan dana yang dimiliki oleh pengambilan keputusan.

\subsection{Sistem Akutansi Pemerintah Daerah}

Sistem akuntansi pemerintah daerah adalah semua kegiatan yang mencakup pengumpulan data, pengklasifikasikan, pembukuan dan pelaporan atas transaksi keuangan pemerintah daerah. pada pemendagri Nomor 13 Tahun 2006 pasal 232 ayat (3) meliputi rangkaian prosedur mulai dari proses pengumpulan data, pencatatan, pengelolaan dan ringkasan atas transaksi dan kejadian keungan serta laporan keuangan dalam rangka pertanggunjawaban pelaksanaan APBD yang dapat dilakukan secara manual atau mengunakan aplikasi komputer.

Sistem akuntansi pemerintah daerah menunjukan siklus akuntansi dalam pemerintah daerah. secara garis besar terdiri atas empat prosedur akuntansi yaitu: prosedur akuntansi penerimaan kas, prosedur akuntansi pengeluaran kas, prosedur akuntasi selain kas dan prosedur akuntansi barang dan jasa (Halim, 2007: 78).

a. Prosedur akuntansi penerimaan kas
Sisem prosedur akuntansi peneriaman kas adalah proses baik manual maupun terkomputerisasi mulai pencatatan, penggolongan dan peringkasan transaksi dan/atau kejadian keuangan serta laporan keuangan dalam rangka pertanggungjawaban pelaksanaan APBD yang berkaitan dengan penerimaan kas pada SKPD dan SKPKD.

b. Prosedur akuntansi pengeluaran kas Prosedur akuntansi pengeluaran kas adalah serangkaian proses baik manual maupun terkomputerisasi yang mualai pencatatan, penggolongan dan peringkasan transaksi dan/atau kejadian keuangan serta pelaporan keuangan dalam rangka pertanggungjawaban pelaksanaan APBD yang berkaitan dengan pengeluaran kas pada SKPD dan/SKPKD.

c. Prosedur akuntasi selain kas

Prosedur akuntansi selain kas adalah serangkaian proses baik manual maupun terkomputerisasi yang mulai pencatatan, penggolongan dan peringkasan transaksi dan/atau kejadian keuangan serta pelaporan keuangan dalam rangka pertanggungjawaban pelaksanaan APBD yang berkaitan dengan transaksi dan/atau selain kas pada SKPD dan/SKPKD.

d. Prosedur akuntansi barang

Prosedur akuntansi asset adalah serangkaian proses baik manual maupun terkomputerisasi yang mulai pencatatan dan pelaporan 


\begin{abstract}
akuntasi atas perolehaan pemeliharaan, rehabilitasi, penghapusan, pemindahtangan, perubahaan klasifikasi dan penyusunan terhadap asset tetap yang dikuasai/digunakan SKPD dan/atau SKPKD.
\end{abstract}

\subsection{Akuntansi Keuangan Daerah}

Akuntansi keuangan daerah adalah proses pengidentifikasian, pengukuran, pencacatan dan pelaporan transaksi ekonomi (keuangan) dari entitas pemerinath daerah (provinsi kabupaten, kota) yang disajikan sebagai informasi dalam rangka pengambilan keputusan ekonomi yang diperlukan oleh pihak-pihak eksternal entitas pemerintah daerah (kabupaten/kota dan provinsi). Pihakpihak eksternal entitas pemda yang memerluka informasi yang dihasilkan oleh akuntansi keuangan daerah tersebut antara lain adalah dewan perwakilan rakyat daerah (DPRD), Badan Pengawasan keuangan, investor, kreditur, donator; analisis ekonomi dan pemerhati pemerintah daerah, rakyat, pemda lain serta pemerintah pusat yang seluruh berada dalam lingkungan akuntansi keuangan daerah (Halim, 2007: 42).

Proses pengidentifikasian adalah mengidentifikasi ekonomi agar dapat membedakan transaksi yang bersifat ekonomi. Transaksi ekonomi yaitu dengan mengukur satuan keuangan jadi seluruh transaksi dalam akuntansi harus dinyatakan dalam satuan uang. Proses pencatatan transaksi ekonomi yaitu pengelolaan data transaksi ekonomi tersebut melalui penambahan dan atau pengukuran sumber daya selanjutnya pelaporan trasaksi ekonomi akan menghasilakan laporan keuangan yang merupakan hasil akhir proses akutansi.

Sebelum era reformasi keuangan daerah, pengertian pencatatan akuntansi keuangan daerah selama ini adalah pembukuan. Pada hal menurut akuntansi pengertian tersebut tidak tepat hal ini disebabkan karena menggunakan sistem pencatatan yang digunakan yaitu sistim pencatatn single entry, double entry dan triple entry.

Sistem pencatatan single entry sering disebut juga tata buku tunggal atau tata buku, dalam sistem pencatatn dilakukan dalam satu kali, transksi yang berakibat tambahnya kas akan dicatat pada sisi penerimaan dan transaksi yang berakibat berkurangnya kas akan dicatat pada sisi pengeluaran. sedangkan sistem pencatatan double entry sering disebut juga sistem tata buku berpasangan dalam pencatatan dilakukan dua kali, pencatatan dengan sistem ini sebut dengan istilah menjurnal, dimana sisi debet berada di sebelah kiri sedangkan sisi kredit berada di sebelah kanan. Adapun persamaan dasar akuntansi sebagai berikut.

AKTIVA + BELANJA $=$ HUTANG + EKUITAS + PENDAPATAN 
Sistem pencatatan Triple entry adalah pelaksanaan pencatatan dengan mengunakan sistem pencatatan double entry, ditambah pada pencatatan buku anggran. Sistem pembukuan yang dilaksanakan sebelum aturan Kepmendagri No 29 Tahun 2002 adalah sistem pembukuan tunggal. Sistem pembukuan yang disarankan oleh Kepmendagri adalah sistem pembukuan pasangan (double entry) dimana setiap transaksi keuangan atau ekonomi dicatat pada posisi debet dan rekening lainnya dicatat disisi kredit.

\subsection{Sistem Akuntansi Keuangan Daerah}

Menurut Halim (2007: 51-52) akuntansi adalah suatu sistem yaitu suatu kesatuan yang terdiri atas subsistem-subsistem atau kesatuan lebih kecil yang saling berhubungan dengan mempunyai tujuan tertentu. Suatu sistem mengolahan input (masukan) mejadi output (keluar). Input sistem akuntasi adalah buktibukti trasnsaksi dalam bentuk dokumen, formulir. Output adalah laporan keuangan. Dalam proses akuntansi terdapat beberapa catatan yang dibuat yaitu jurnal buku besar, buku pembantu apabila digambarkan sistem akuntasi tersebut akan tampak seperti yang ditunjukan gambar di bawah ini.

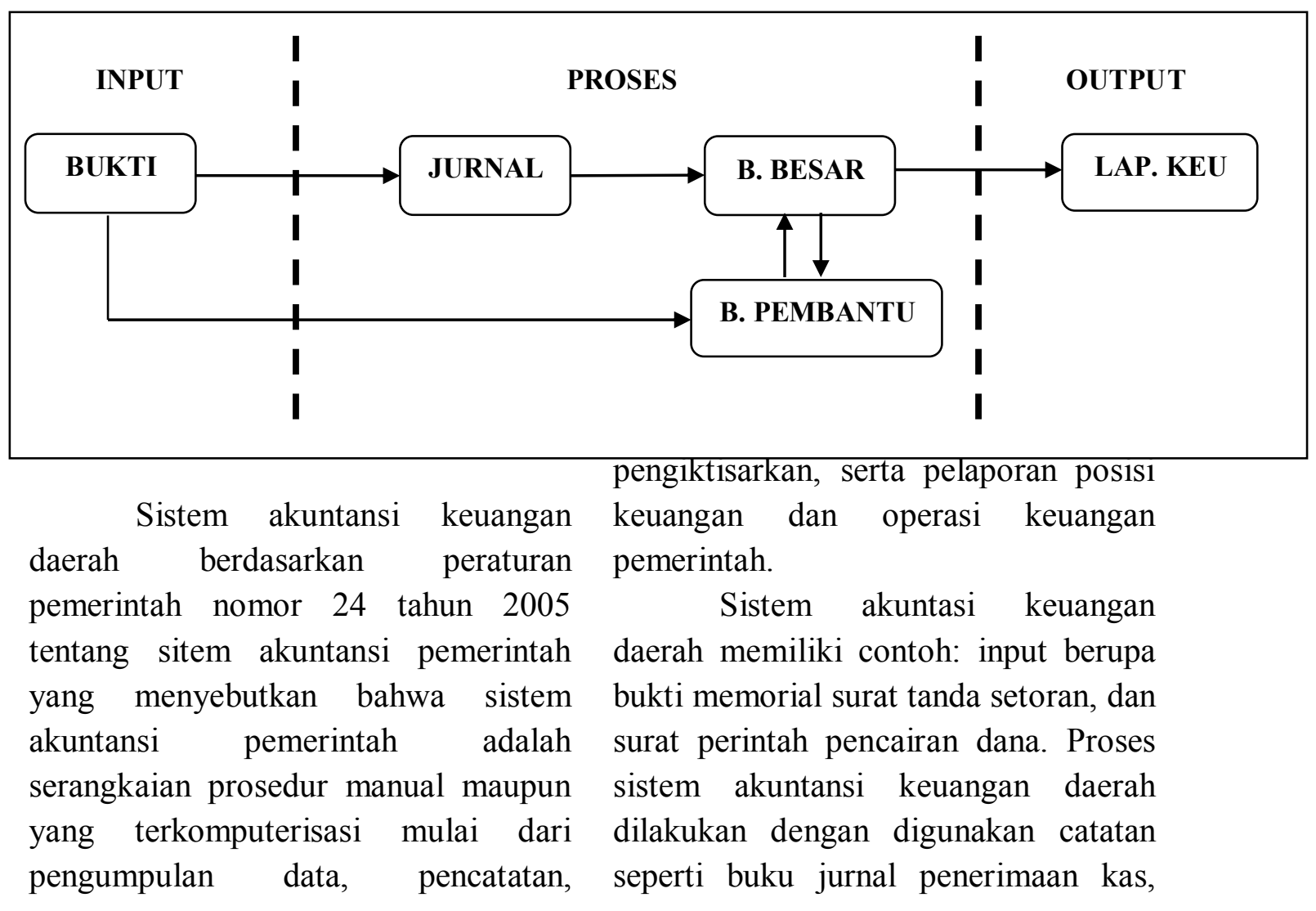


buku jurnal pengeluaran kas, buku besar dan buku pembantu. Output sistem akuntansi keungan daerah berupa laporan keuangan yang meliputi laporan realisasi anggaran, neraca, laporan arus kas dan catatan atas laporan keuangn (Pemendagri nomor 13 tahun 2006).

Sistem akuntansi dapat dijelaskan secara rinci melalui siklus akuntansi dapat dilihat Sugiri (2004:1314) yang mana ada 9 (Sembilan) tahap/proses yang wajib dijalani dalam kegiatan akuntansi secara manual sebagai berikut:

a. Mendokumentasi transaksi keuangan dalam bukti transaksi dan melakukan analisis transaksi keuangan tersebut.

b. Mencatat transaksi keuangan dalam buku jurnal, tahapan ini disebut menjurnal. c. Meringkas, dalam buku besar, trasaksi-trasaksi keuangan yang sudah di jurnal. Tahapan ini sebut Posting atau mengakunkan.

d. Menentukan saldo-saldo buku besar di akhir periode dan menuangkannya dalam neraca saldo.

e. Menyesuaikan buku besar pada informasi yang paling up-to-date (mutakhir).

f. Menentukan saldo-saldo buku besar setelah penyesuaian dan menuangkannya dalam neraca saldo setelah penyesuaian (NSSP).

g. Menyusung laporan keuangan berdasarkan pada NSSP.

h. Menutup buku besar.

i. Menentukan saldo-saldo buku besar dan menuangkannya dalam neraca saldo setelah tutup buku.

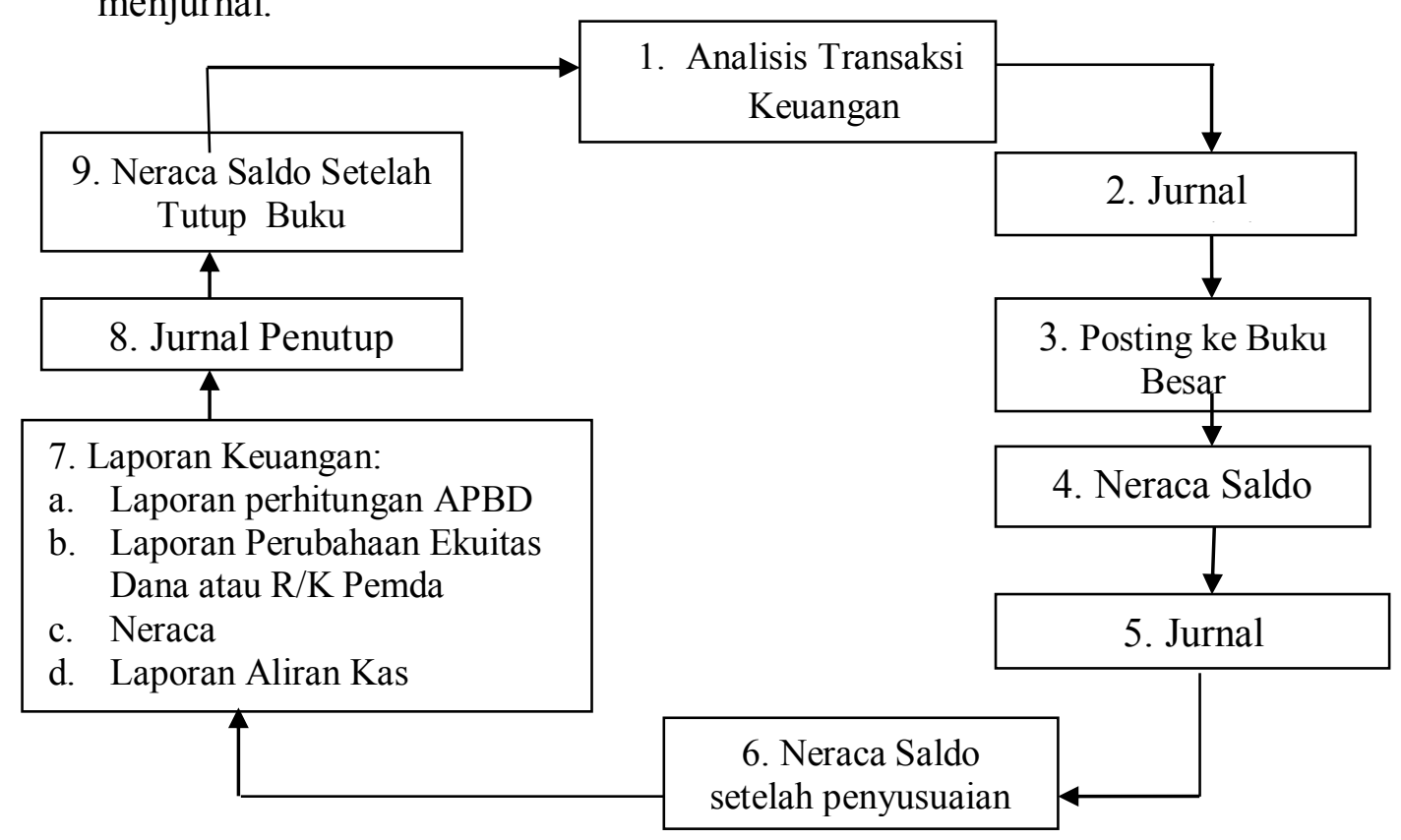

Gambar 2

Siklus Akutansi 
Di samping itu, terdapat dua prosedur yang sifatnya tidak wajib yaitu neraca lajur dan jurnal pembalikan. Neraca lajur digunakan untuk mempermudah tahapan-tahapan berikut: penyesuaian, neraca saldo setelah penyesuaian, laporan keuangan, dan penutupan buku. Apabila neraca lajur digunakan, maka penyelenggaraannya adalah sebelum tahapan nomor 5 dari siklus akuntansi. Setelah neraca lajur selesai maka dapat segera disusun laporan keuangan tanpa harus menyelenggarakan lebih dulu tahapan-tahapan nomor 5 dan 6 .

Siklus akuntansi pada periode tertentu berakhir pada tahapan nomor 9 seperti penjelasan sebelumnya. Pada periode berikutnya, siklus akuntansi dimulai lagi dari tahapan nomor 1 . Namun, ada prosedur atau tahapan yang disebut jurnal pembalikan yang sifatnya tidak wajib. Tahapan ini diselenggarakan semata-mata hanya untuk mempermudah penyelenggaraan akuntansi pada periode berikutnya sebelum penjurnalan transaksi. Jadi jurnal pembalikan diselenggarakan pada hari kerja pertama sebelum terjadi transaksi keuangan (misalnya tanggal 2 Januari jika periodenya adalah tahun kalender).

\subsection{Sistem Informasi Manajemen Daerah (SIMDA)}

Secara umum, Sistem Informasi Manajemen (SIM) merupakan suatu sistem yang dapat membantu manajemen di dalam pengumpulan data, pengolahan serta analisis evaluasi data dan menyajikan ke dalam batas informasi yang bernilai dan akhirnya sampai pada pengambilan keputusan di mana informasi ini berguna untuk mendukung fungsi operasi manajemen (Machmud, Rizan. 2013). Aplikasi Sistem Informasi Manajemen Daerah yang dikembangkan oleh Badan Pengawasan Keuangan dan Pembangunan (BPKP) dan dikenal dengan Aplikasi SIMDA merupakan salah satu produk dari teknologi sistem informasi yang digunakan oleh banyak pemerintah daerah di Indonesia dalam menyelenggarakanpengelolaan

keuangan daerahnya. Menurut Djaja dalam (Budiman, Fuad dan Arza, Fefri Indra. 2013), Aplikasi SIMDA merupakan aplikasi database yang bertujuan untuk mempermudah pengelolaan keuangan daerah di lingkungan Satuan Kerja Perangkat Daerah (SKPD). Aplikasi SIMDA dikembangkan dengan memperhatikan dan mengimplementasikan Sistem Pengendalian Intern Pemerintah (SPIP). Oleh sebab itu pengendalian terhadap aplikasi menjadi suatu keharusan untuk menjadi pedoman bagi pemerintah daerah dalam mengimplementasikan Aplikasi SIMDA untuk menghasilkan Laporan Keuangan Pemerintah Daerah (LKPD).

\subsection{Pengelolaan Keuangan Daerah}

Menurut Mahmudi (2007: 14) pengelolaan keuangan daerah adalah tahapan-tahapan yang harus dilakukan dalam mengelola keuangan daerah yang menjadi wewenang dan tanggunjawab pemerintah daerah agar 
pengelolaan keuangan darah tersebut pada dasarnya, terdiri dari tiga tahap memenuhi prinsip ekonomi, efisien, yaitu; (1) tahap perencanaan, (2) tahap efektivitas, transparan dan akuntanbel. pelaksanaan atau implementasi dan (3) Siklus pengelolaan keuangan daerah tahap pelaporan dan evaluasi kinerja.

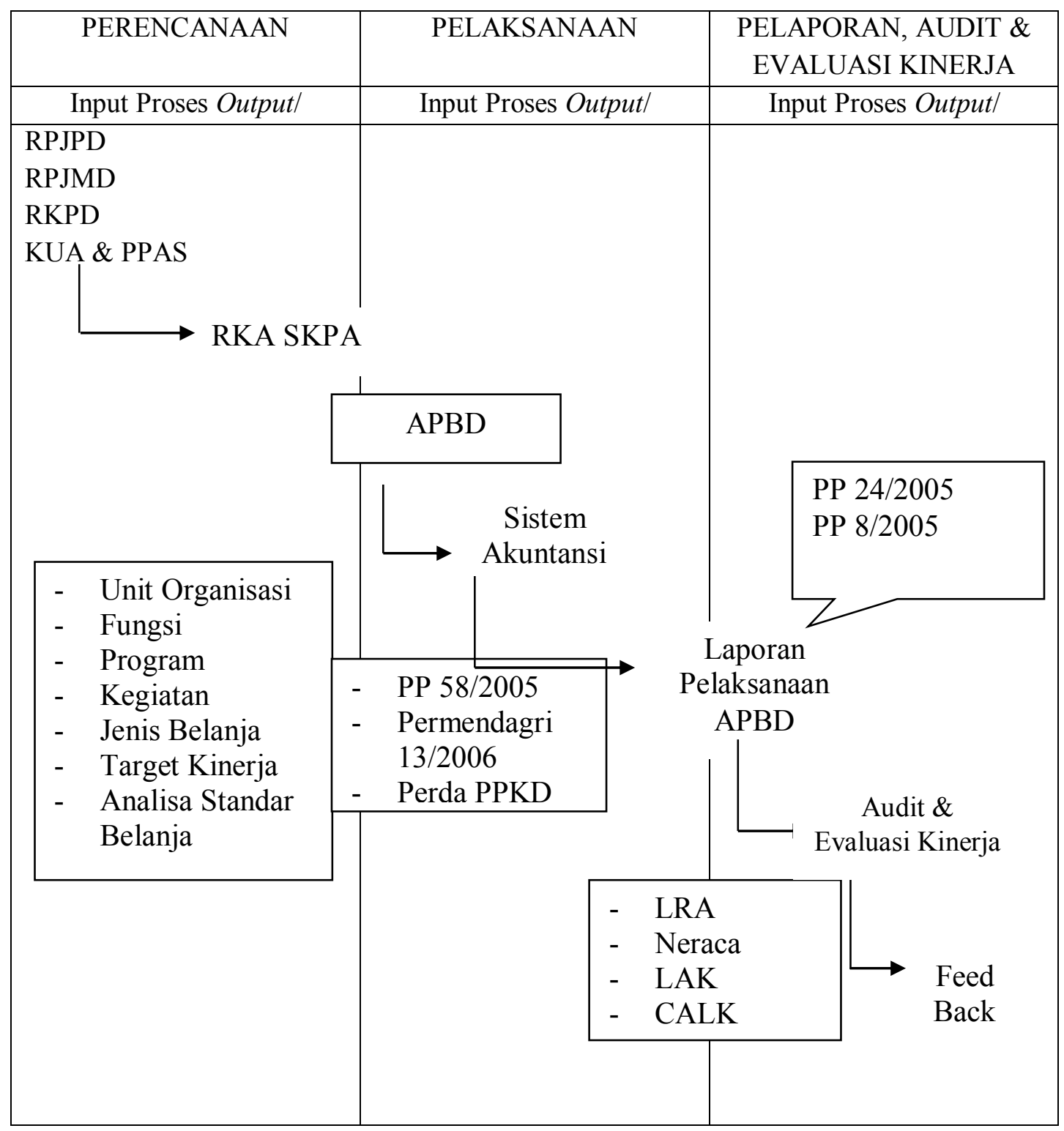

Sumber: Mahmudi (2007: 14)

Gambar 3

Siklus Pengelolaan Keuangan Daerah 
a. Tahap Perencanaan

Dalam siklus pengelolaan keuangan daerah, tahap perencanaan merupakan tahap yang sangat krusial. Peran DPRD dan masyarakat dalam tahap perencanaan ini sangat besar. Kualitas hasil (outcome) dari pengelolaan keuangan daerah sangat dipengaruhi oleh seberapa bagus perencanaan yang dibuat. Pada tahap perencanaan ini dapat dipilah menjadi tiga bagian, yaitu apa yang menjadi input, proses, dan outputnya. Input dalam tahap perencanaan ini berupa dokumen perencanaan yang dimiliki pemerintah daerah. Perencanaan itu sendiri pada dasarnya juga terdapat proses yang harus dilakukan sehingga menghasilkan output perencanaan berupa dokumen perencanaan daerah. Dokumen perencanaan pemerintah daerah tersebut meliputi.

1). Rencana Pembangunan Jangka Panjang Daerah (RPJPD).

2). Rencana Pembangunan Jangka Menengah Daerah (RPJMD).

3). Rencana Kerja Pemerintah Daerah (RKPD).

4). Rencana Strategis Satuan Kerja Perangkat Daerah (Renstra SKPD).

5). Rencana Kerja Satuan Kerja Perangkat Daerah (Renja).
6). Kebijakan Umum APBD (KUA).

7). Prioritas dan Plafon Anggaran Sementara (PPAS).

Dokumen perencanaan daerah dapat dikategorikan menjadi dua bentuk, yaitu.

1). Dokumen perencanaan pembangunan daerah berupa RPJPD, RPJMD, dan RKPD yang memuat visi, misi, tujuan, kebijakan, strategi, program, dan kegiatan.

2). Dokumen perencanaan keuangan daerah berupa kebijakan Umum APBD, Prioritas dan Plafon Anggaran, serta RAPBD.

Perencanaan pembangunan daerah disusun berdasarkan jangka waktu perencanaan, yaitu 20 tahun untuk RPJPD, 5 tahun untuk RPJMD, dan 1 tahun untuk RKPD, sedangkan untuk perencanaan keuangan daerah berupa RAPBD berlaku untuk satu tahun.

Output dari tahap perencanaan ini adalah berupa RAPBD. Mengapa RAPBD menjadi output utama dalam perencanaan ini? Hal ini karena bagi pemerintah daerah APBD merupakan tulang punggung (backbone), atau cetak biru (blue print) pembangunan daerah. APBD memiliki fungsi penting dalam 
melakukan distribusi, alokasi, dan stabilisasi keuangan di daerah. Oleh karena itu, RAPBD menjadi sangat penting bagi daerah, arah dan orientasi pembangunan daerah dapat tergambar di RAPBD tersebut.

Sebelum menjadi RAPBD, terdapat proses yang harus dilalui yaitu proses perencanaan anggaran. Proses perencanaan anggaran terdiri dari dua pendekatan, yaitu pendekatan perencanaan dari atas (top down) dan partisipatif (bottom up). Pendekatan top down adalah berupa penentuan. Kebijakan Umum APBD serta penetapan prioritas dan plafon anggaran sedangkan perencanaan bottom up adalah berupa usulan program, kegiatan, dan anggaran dari masing-masing uni kerja (SKPD).

b. Tahap Pelaksanaan

Output dari tahap perencanaan adalah berupa RAPBD yang disahkan oleh DPRD menjadi APBD. Output perencanaan tersebut akan menjadi input bagi tahap pelaksanaan, yaitu implementasi anggaran. Dalam tahap pelaksanaan anggaran terdapat suatu proses berupa sistem akuntansi pemerintah daerah. Sistem akuntansi pemerintah daerah ini sangat penting, karena bagaimanapun bagusnya perencanaan anggaran apabila dalam tahap implementasi tidak terdapat system akuntansi yang memadai, maka banyak hal yang direncanakan tidak akan mencapai hasil yang diinginkan. Sistem akuntansi yang buruk akan memicu terjadinya kebocoran anggaran, inefisiensi, dan ketidakakuratan laporan keuangan. Melalui system akuntansi pemerintah daerah itulah akan dihasilkan laporan pelaksanaan anggaran yang merupakan output dari tahap pelaksanaan.

c. Tahap Pelaporan

Output dari tahap pelaksanaan yang berupa laporan pelaksanaan anggaran akan menjadi input bagi tahap pelaporan. Input tersebut akan diproses lebih lanjut untuk menghasilkan output berupa laporan keuangan yang akan dipublikasikan. Proses pelaporan tersebut dilakukan dengan mengacu pada standar Akuntansi Pemerintah yang sudah ditetapkan. Setelah disesuaikan dengan standar Akuntansi pemerintahan, maka laporan keuangan daerah siap untuk di audit oleh auditor independen, selanjutnya setelah diaudit dapat didistribusikan kepada DPRD dan dipublikasikan kepada masyarakat luas. Laporan keuangan publikasian yang sudah diaudit tersebut selanjutnya dapat digunakan sebagai bahan untuk evaluasi kinerja dan memberikan umpan balik bagi perencanaan periode berikutnya.

Ketiga tahap tersebut membentuk suatu siklus, maka output yang dihasilkan dari tahap 
tertentu akan menjadi input bagi tahap berikutnya. Output yang dihasilkan dari tahap perencanaan akan menjadi input bagi tahap pelaksanaan, output dari tahap pelaksanaan akan menjadi input bagi tahap pelaporan dan evaluasi kinerja dan output bagi tahap pelaporan dan evaluasi kinerja akan menjadi input bagi tahap perencanaan periode berikutnya.

\subsection{Kerangka Pikir}

Pengelolaan keuangan daerah yang baik ditunjukan dari laporan keuangan yang disusun dan telah diaudit. Suatu laporan keuangan haruslah memenuhi kualitas laporan keuangan yang sesuai dengan kerangka konseptual akuntansi yang juga tertuang dalam PP No. 71 tahun 2010 yang menjadi dasar hukum Standar Akuntansi Pemerintahan, dimana kriteria tersebut meliputi relevan, andal, dapat dibandingkan, dan dapat dipahami. Pemerintah daerah diwajibkan menyusun laporan pertanggungjawaban yang menggunakan sistem akuntansi yang diatur oleh pemerintah pusat dalam bentuk undang-undang dan peraturan pemerintah yang bersifat mengikat seluruh pemerintah daerah.

Dalam melaksanakan kegiatan pelayanan publik dan pembangunannya, pemerintah Daerah memiliki kewenangan mengelola keuangan daerah. Pengelolaan keuangan daerah tersebut harus memenuhi azas transparansi dan akuntabilitas, dan hal itu dimanifestasikan dalam bentuk Laporan Keuangan Daerah. Pelaporan keuangan daerah harus memenuhi syarat-syarat kualitas laporan keuangan yang sudah ditentukan. Dalam hal ini, penggunaan SIMDA diharapkan dapat meningkatkan kualitas isi laporan keuangan daerah tersebut.

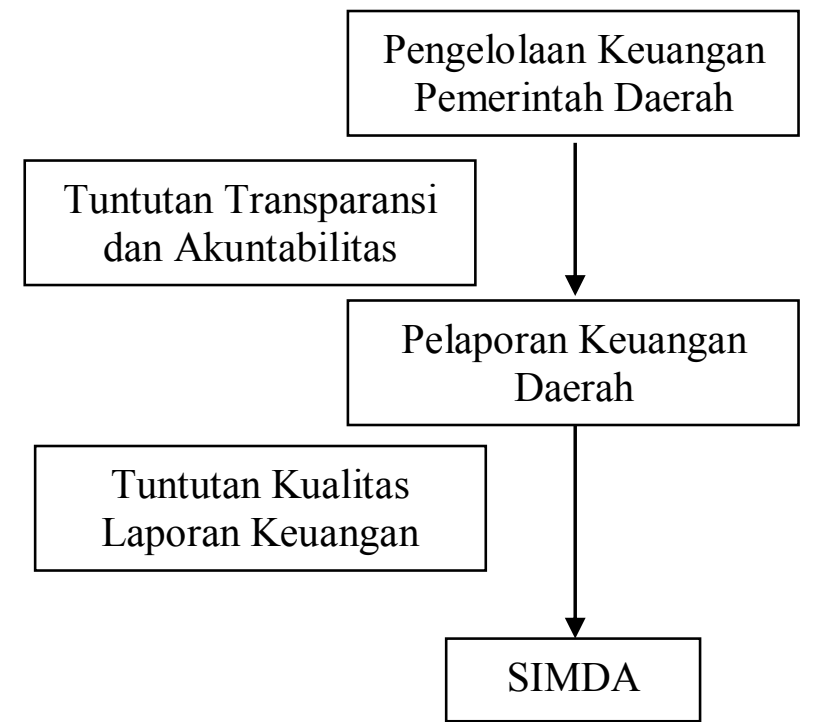

Gambar 4

Kerangka Pemikiran Penelitian 


\section{METODE PENELITIAN}

\section{Desain Penelitian}

Penelitian ini adalah penelitian kualitatif dengan jenis pendekatan studi kasus (case study). Penelitian studi kasus bertujuan untuk mendalami suatu kasus tertentu secara lebih mendalam dengan melibatkan pengumpulan beraneka sumber informasi. Cresswell mendefinisikan studi kasus sebagai suatu eksplorasi dari sistem-sistem yang terkait (bounded system) atau suatu kasus (Raco. J.R. 2010).

\section{Tempat dan Waktu Penelitian}

Penelitian ini dilaksanakan dengan mengambil lokasi penelitian di Kantor Badan Perencanaan Pembangunan Daerah (Bappeda), Kantor Inspektorat dan Kantor DPPKAD Kabupaten Purworejo Provinsi Jawa Tengah. Adapun pelaksanaan penelitian dilakukan dari bulan Maret sampai dengan Mei tahun 2016.

\section{Subjek Penelitian}

Subjek dalam penelitian ini adalah pejabat,kepala bagian dan para staf di lingkungan Bappeda Kabupaten Purworejo, Inspektorat Kabupaten Purworejo,dan DPPKAD Kabupaten Purworejo.Pegawai di Kabupaten Purworejo dalam penelitian ini antara lain Kepala dan Kasubag SKPD, Sekretaris, Kasubag Keuangan, Kasubag Perencanaan dan Pelaporan, Kasubag Umum dan Kepegawaian, Kabid Perekonomian, Kabid Pemerintahan \& Sosial Budaya, Kabid
Prasaranan dan Pengembangan Wilayah serta Kabid Statistik, Penelitian, Pengembangan \& Pengendalian.

\section{Populasi, Sampel dan Teknik \\ Pengampilan Sampel}

Data dalam penelitian ini ada dua yaitu, data primer dan data sekunder. Data primer adalah data berupa informasi langsung yang didapat darisubjek/responden penelitian, sedangkan data sekunder adalah data yang sifatnya dokumentasi. Data primer didapatkan dari Pejabat dan para staf pada Kantor Bappeda yang ditentukan sebagai responden penelitian. Data sekunder berupa dokumen Laporan Keuangan Pemerintah Daerah (LKPD).

\section{Teknik Pengumpulan Data}

Teknik pengumpulan data yang dilakukan dalam penelitian ini adalah wawancara.

\section{Metode Analisis}

Analisis data adalah proses mengatur urutan data, mengorganisasikannya dalam suatu pola, kategori, dan satuan uraian dasar. Analisis data berbeda dengan penafsiran data. Analisis data lebih memberikan arti yang signifikan terhadap analisis, menjelaskan pola uraian, dan mencari hubungan di antara dimensi-dimensi uraian. Teknik analisis data yang digunakan dalam penelitian ini adalah analisis kualitatif yang didukung oleh data 
kuantitatif. Dalam analisis kualitatif, langkah-langkah analisis yang sering digunakan untuk memahami komponen-komponen data adalah melalui (1) reduksi data, (2) penyajian data dan (3) menarik kesimpulan/verifikasi (Miles and Huberman, 1994: 10). Reduksi data merujuk pada proses pemilihan dan pemilahan (selecting), pengerucutan (focusing), penyederhanaan (simplifying), peringkasan (abstracting), dan transformasi data (transforming).

\section{HASIL PENELITIAN DAN PEMBAHASAN \\ Gambaran Umum Tingkat \\ Penerapan SIMDA}

1. Tujuan Pelaksanaan SIMDA

Tujuan dari penerapan SIMDA Keuangan pada SKPD di Kabupaten Purworejo adalah untuk menghasilkan laporan keuangan secara tepat waktu,lengkap, akurat, dan dapat diandalkan sesuai ketentuan yang berlaku.selain itu agar mampu menghasilkan laporan keuangan yang berkualitas.

2. Tingkat pemakaian kebijakan SIMDA

Pemerintah daerah Purworejo mulai melaksanakan SIMDA pada tahun 2009. Lewat asistensi/pendampingan dari BPKP, pemerintah daerah mulai melaksanakan aplikasi SIMDA. Idealnya, SIMDA dijalankan mulai dari penganggaran, penatausahaan, hingga laporan keuangan.
Pembelajaaran SIMDA dilakukan pada SKPD (Satuan Kerja Perangkat Daerah). SIMDA yang sudah berjalan efektif adalah SIMDA asset, SIMDA pendapatan, SIMDA keuangan dan SIMDA acrual

Hasil wawancara menunjukan dengan aplikasi ini, Pemerintah Daerah dapat melaksanakan pengelolaan keuangan daerah secara terintegrasi, dimulai dari penganggaran, penatausahaan hingga akuntansi dan pelaporannya. Fitur-fitur yang digunakan pun cukup sederhana, mudah dimengerti dan dipelajari. Dengan melakukan transaksi keuangan pemerintah daerah seharihari menggunakan aplikasi ini (output dokumen transaksi seperti SPD, SPP, SPM, dan SP2D), secara otomatis catatan dan laporan keuangan dapat dihasilkan (output catatan akuntansi seperti buku jurnal, buku besar, dan laporan.

\section{Ketersediaan Sarana SIMDA}

Sarana yang diperlukan dalam implementasi SIMDA tergolong sederhana. Sarana yang diperlukan hanya berupa komputer, aplikasi SIMDA, dan jaringan internet. Aplikasi SIMDA diinstalasikan ke dalam komputer sesuai petunjuk pemakaian yang dikeluarkan oleh BPKP. Setelah instalasi, komputer harus dikoneksikan ke server lewat jaringan internet. Server SIMDA berada di Dinas DPKAD. DPKAD menjadi lokasi server karena dinas ini yang langsung 
menangani sistem informasi keuangan daerah tersebut. SKPD kemudian datang ke dinas DPKAD untuk mendapatkan nama pengguna dan kata kunci untuk masuk ke dalam server. Karena sarana yang diperlukan tergolong sederhana, maka sarana-sarana ini sepenuhnya tersedia pada SKPD-SKPD. Dinas Pendapatan, Pengelolaan Keuangan dan Asset Daerah Kabupaten Purworejo memiliki PC Unit 54 unit, UPS 5 unit,. Note Book 32 unit, mainframe 22 unit.

\section{Hasil}

wawancara

mrnunjukan faktor eksternal penghambat bahwa sistem yang digunakan Pemda Purworejo dari BPKP jadi penggunaan menurut BPKP dan sistem itu belum sempurna karena masih terdapat beberapa kendala koneksivitas komputer kerja ke server pusat SIMDA dan adanya masalah bug pada program sehingga program seringkali hang. Masalah lainnya adalah register progam dari BPKP yang bertele-tele dan membutuhkan waktu lama. nomor register SIMDA bisa langsung didapatkan dari BPKP pengelola aplikasi SIMDA. Namun kalau misalnya terjadi masalah pada komputer, misalkan komputer kena virus dan mesti diinstall ulang, maka otomatis aplikasi ini pun turut serta harus install ulang. Masalah semakin bertambah ketika ini terjadi pada saat tenggat waktu untuk segera melaporkan keuangan, sedangkan meminta nomor register cukup memakan banyak waktu dan pengguna tidak bisa masuk aplikasi ini karena muncul Register Aktifasi SIMDA.

Selain itu kualitas hardware komputer untuk mengoperasikan SIMDA belum semua SKPD bagus masih banyak kualitas komputer yang belum mendukung.Jaringan maupun LAN intranet bagian PDE server sering mati dan jika cuaca mendung atau hujan sering ada gangguan

4. Proses-Proses dalam SIMDA.

Semua proses yang terjadi di dalam mekanisme penyusunan laporan keuangan lewat SIMDA merujuk pada Peraturan Menteri Dalam Negeri No 13 tahun 2006 tentang Pedoman Pengelolaan Keuangan Daerah. a. Proses Penyusunan RKA, b. Proses Penyusunan DPA, c. Proses Pembuatan Anggaran Kas, d. Proses Pergeseran Anggaran, e. Proses Perubahan Anggaran.

\section{Kemampuan Kerja SDM SIMDA}

1. Kualitas dan Kuantitas SDM untuk Pelaksanaan SIMDA

Pengguna SIMDA terdiri dari beberapa level mulai dari operator berupa PPK (Pejabat Penatausahaan Keuangan), bendahara pengeluaran, dan bendahara pendapatan, serta pejabat Pengelola Keuangan Daerah dan Auditor dari 
Inspektorat, supervisor dari pejabat pengelola keuangan daerah, administrator dari dua orang pejabat pengelola keuangan daerah. Pada dasarnya pendidikan bukanlah masalah. Karena SIMDA dirancang dengan interface yang baik, asalkan individu mau belajar maka ia dapat memahami dan menggunakan SIMDA.Namun permasalahan juga timbul karena mereka yang memiliki pendidikan akuntansi kurang memahami TI (Teknologi informasi).kebalikannya yang memahami TI tentu pemahaman terhadap akuntansi pasti kurang.oleh karena itu pegawai pemerintah yang paham akan akuntansi dibekali harus sering dibekali diklat IT sehingga mampu mengunakan SIMDA dengan baik. Di Kabupaten Purworejo Ditemukan bahwa mayoritas pendidikan pegawai pengguna SIMDA adalah S1, sisanya Magister, diploma 3 dan SMA.

Dari hasil wawancara PPK SKPD mengeluhkan kurangnya dukungan dari staf verifikasi dan akuntansi di bagiannya. Bahkan karena kurangnya staf yang membantunya, terpaksa Bendahara Pengeluaran ikut membantu dalam melakukan verifikasi dan menyusun laporan keuangan. Hal ini tentu sangat mengganggu pelaksanaan SIMDA.Kondisi ini disebabkan kurangnya perhatian dan komitmen kepala daerah akan kebutuhan SDM pendukung fungsi PPK SKPD.
2. Tingkat Pengalaman Pegawai dalam

Pelaksanaan SIMDA

Pemerintah daerah Purworejo mulai melaksanakan SIMDA pada tahun 2009 maka paling lama pengalaman pegawai dalam pelaksaan SIMDA adalah 7 tahun.Pengalaman pegawai dalam pelaksanaan SIMDA tergantung dari usia kerja mereka pada tugas SIMDA. Pegawai yang berpengalaman tinggi diharapkan mampu bertugas sebagai administator. Sementara itu, pada tingkat operator, pengalaman yang diperlukan dalam bentuk kesesuaian dengan SOP.

3. Program Pengembangan SDM lewat Diklat (Bimtek) SIMDA

Karena tidak bertopang pada latar pendidikan formal, maka kompetensi dari SDM SIMDA harus bertopang pada kinerja diklat. Hal pertama yang diajarkan adalah bagaimana menggunakan SIMDA. Pelatihan dasar ini mencakup cara menginput data anggaran dan penatausahaan, cara membuat laporan, cara melakukan peninjauan, dan cara melakukan analisis. Pelatihan dilakukan oleh pemerintah daerah dengan berkoordinasi dengan BPKP sebagai pemegang hak cipta dari SIMDA. Pelatihan dilakukan pada seluruh pengguna SIMDA, termasuk PPK. PPK dilibatkan karena ia diperlukan untuk melakukan pengesahan mengenai kesesuaian data yang dimasukkan bendahara dalam 
SIMDA. Diklat dilakukan setiap tahun tiga kali. Pengguna SIMDA Kabupaten Purworejo semuanya telah mengikuti Bimbingan Teknis (BIMTEK) SIMDA Keuangan.

\section{Tingkat Partisipasi dalam Implementasi SIMDA}

1. Tingkat Partisipasi SKPD

Proses umpan balik dalam penggunaan SIMDA ditemukan tidak semua SKPD aktif menggunakannya.Menurut hasil wawancara ada empat SKPD yang aktif yaitu DPPKAD,Dinas Pendidikan dan Kebudayaan, BAPPEDA dan Inspektorat. SKPD ini aktif dalam memberikan masukan jika ada program yang tidak sesuai yang diharapkan.

\section{Tingkat Partisipasi SDM}

Dilihat dari SDM, pasti terdapat tingkat perbedaan partisipasi yang berusia muda dengan yang sudah berumur.yang berusia muda aktif dalam mengunakan komputer sementara yang yang berusia 45 tahun keatas tidak terlalu aktif mengunakan komputer.

\section{Kesimpulan}

Hasil penelitian diketahui bahwa proses penggunaan SIMDA telah sesuai dengan amanat Peraturan Menteri Dalam Negeri No 64 tahun 2013 tentang Penerapan Standar Akuntansi Pemerintahan Bernasis Akrual. Namun Tingkat partisipasi penggunaan SIMDA berdasarkan SKPD masih rendah. Berdasarkan hasil analisa disimpulkan penerapan dan penilaian SIMDA di Kabupaten Purworejo dalam membantu pengelolaan akuntansi pemerintahan sebagai berikut:

1. Aplikasi SIMDA di Kabupaten Purworejo dengan sistem akrual mampu manghasilkan informasi dengan ketepatan atau tingkat kebenaran yang lebih baik bila dibandingkan dengan pengolahan data manual sehingga sangat membantu pengelolaan Akuntansi Pemerintahan

2. Hasil Laporan Akuntansi Pemerintahan tersebut Membantu Pimpinan (Kepala Daerah, Sekretaris Daerah, Kepala SKPD selaku Pengguna Anggaran) dalam mengambil keputusan sesuai data dan informasi yang ada.

3. Sistem Pengendalian Intern berjalan dengan baik dimulai dari Penganggaran, Penatausahaan sampai pada pelaporan keuangan daerah.

4. Faktor-faktor yang ditemukan selain SIMDA terhadap kualitas laporan keuangan adalah faktor SDM, kepemimpinan kepala derah, umpan balik terhadap rekomendasi BPK, dan konsistensi dalam penerapan SIMDA. 


\section{Saran - saran}

Saran yang dapat diajukan dalam penelitian ini antara lain:

1. Pemerintah Kabupaten Purworejo harus konsisten dan komitmen memperhatikan SIMDA khususnya PPK (Pejabat Penatausahaan Keuangan) karena yang berperan dalam verifikasi laporan keuangan.Pada formasi penerimaan PNS yang diusulkan kepada pemerintah pusat setiap tahunnya. Meskipun formasi yang diusulkan setiap tahun tidak banyak, namun jika direncanakan secara baik kebutuhan SDM pendukung fungsi PPK SKPD akan terpenuhi dengan baik.Semestinya kebijakan promosi dan penempatan pegawai yang akan menduduki sebagai PPK SKPD mempertimbangkan latar belakang pendidikan pegawai yang sesuai dengan kebutuhan PPK SKPD, pendidikan dan pelatihan keuangan daerah yang pernah diikutinya, dan pengalaman pegawai yang bersangkutan khususnya dalam pengelolaan keuangan daerah.
2. Kepala Daerah meningkatkan kualitas SDM, saranan dan prasarana.

a. Pelatihan penggunaan SIMDA perlu ditingkatkan karena belum semua personel menguasai sampai detail.Juga harus memperoleh diklat SIMDA terus-menerus dan berkelanjutan sesuai perubahan kebijakan pengelolaan akuntansi keuangan daerah yang ada, dan dibarengi dengan kebijakan pola mutasi dan promosi karier.

b. Sosialisasi dan pembelajaran terhadap Standar Akuntansi Pemerintahan

c. Jumlah personel bagian PDE server perlu ditambah

d. Perlu peralatan yang lebih baik lagi karena intranet bagian PDE server sering mati dan jika cuaca mendung sering atau hujan sering ada gangguan

\section{DAFTAR PUSTAKA}

Arikunto, Suharsimi. 2006. Prosedur Penelitian Suatu Pendekatan Praktik. Jakarta: Rineka Cipta.

Budiman, Fuad dan Arza, Fefri Indra. 2013. Pendekatan Technology Acceptance Model dalam Kesuksesan Implementasi Sistem Informasi Manajemen Daerah. Jurnal WRA, 1(1), 87-110

Halim, Abdul 2007, Akuntansi Keuangan Daerah, Edisi Ketiga, Salemba Empat Jakarta. 
Machmud, Rizan. 2013. Hubungan Sistem Informasi Manajemen dan Pelayanan dengan Kinerja Pegawai pada Rutan Makassar. Jurnal Capacity STIE AMKOP Makassar. 9(1), 78-85.

Mahmudi, 2007, Analisis Laporan Keuangan Pemerintah Daerah, UPP STIM YKPN, Jakarta.

Mardiasmo, 2002, Akuntansi Sektor Publik, Andi Offset, Jakarta.

Ole,Ryanlie Halens, 2014, Analisis Implementasi Sistem Informasi Manajemen Daerah (SIMDA) Terhadap Kualitas Laporan Keuangan SKPD (Studi Kasus Pada Dinas PPKAD Kabupaten Minahasa Tenggara), ejournal.unsrat.ac.id/index.php/accountability/article/view/6419

Raco, Jozef. 2010 Metode Penelitian Kualitatif (Jenis, Karakteristik dan Keunggulannya. Jakarta: Grasindo

Republik Indonesia, 2003, Undang-undang No 17 Tahun 2003, tentang Keuangan Negara, Jakarta.

Republik Indonesia, 2004, Undang-undang No 32 Tahun 2004 tentang Pemerintahaan Daerah, Jakarta.

Republik Indonesia, 2004, Undang-undang No 33 Tahun 2004, tentang Perimbangan Keuangan antara Pemerintah Pusat dan Pemerintah Daerah, Jakarta.

Republik Indonesia, 2005, Peraturan Pemerintah No 24 Tahun 2005, tentang Sistem Akutansi Pemerintah, Jakarta.

Republik Indonesia, 2005, Peraturan Pemerintah No 58 Tahun 2005, tentang Pengelolaan Keuangan Daerah, Jakarta.

Republik Indonesia, 2006, Pemendagri No 13 Tahun 2006, tentang Pedoman Pengelolaan Keuangan Daerah, Jakarta.

Republik Indonesia, 2006, Peraturan Menteri Dalam Negeri No. 59 tahun 2007 tentang Pedoman Pengelolaan Keuangan Daerah

Santoso, S. 2001. SPSS: Statistik Parametrik. Cetakan kedua, Penerbit PT Elex Media Komputindo Kelompok Gramedia, Jakarta.

Sugiri, Slamet, 2004, Pengantar Akuntansi 1, Edisi ke lima, UPP AMP YKPN, Yogyakarta.

Suwardjono, 2002, Akuntansi Pengantar, Edisi ketiga, BPFE, Yogyakarta. 